\title{
Country Profile
}

\section{Lithuania}

Egdūnas Račius

October 2019

This Country Profile provides a brief overview of religious diversity and its governance in the above-named state. It is one of 23 such profiles produced by GREASE, an EU-funded research project investigating religious diversity, state-religion relations and religiously inspired radicalisation on four continents. More detailed assessments are available in our multi-part Country Reports and Country Cases.

\section{Countries covered in this series:}

Albania, Australia, Belgium, Bosnia and Herzegovina, Bulgaria, Egypt, France, Germany, Greece, Italy, Hungary, India, Indonesia, Lebanon, Lithuania, Malaysia, Morocco, Russia, Slovakia, Spain, Tunisia, Turkey and the United Kingdom.

http://grease.eui.eu 
Total population: 2.8 million

Religious affiliation (percent)

\begin{tabular}{|l|r|}
\hline Roman Catholic & 77.2 \\
\hline Orthodox & 4.1 \\
\hline Old Believer & 0.8 \\
\hline Lutheran & 0.6 \\
\hline Muslim & 0.1 \\
\hline
\end{tabular}

Source: Department of Statistics, Gyventojai pagal tautybę, gimtaja kalbq ir tikybq (Inhabitants by ethnicity, mother tongue and faith, in Lithuanian) (Vilnius: Statistics Lithuania, 2013), https://osp.stat.gov.lt/documents/10180/217110/Gyv kalba tikyba.pdf/1d9dac9a-3d45-4798-93f5$\underline{941 \mathrm{fed} 00503 \mathrm{f}}$

\section{Role of religion in state and government}

Formally, Lithuania is a democratic secular state with no role for religion in politics. In practice, however, the Roman Catholic Church (representing the country's dominant faith) gets preferential treatment from the state and public institutions. For instance, the Roman Catholic Church has its representative on the Council of the national TV and radio broadcaster (LRT); it has its own religious programs on national TV and radio; and its feasts and masses during Easter and Christmas are broadcast on national TV; Roman Catholic priests serve in state institutions (Armed Forces, Border Police) as salaried chaplains and are otherwise routinely invited to consecrate and bless state property (newly opened premises, police cars) and perform rituals at military events (by blessing unit flags). Only feast days of the Roman Catholic Church are public holidays.

There is a political party that self-identifies as Christian democrats and presents itself as promoting Christian values and morale. Their political behavior, however, does not indicate any wish to bring more religion into the public life of the country. Another political party, an ethnic Polish party, also advances conservative Catholic values and would like to see religion play a more prominent role in the state's life, but its electorate is ethnically circumscribed and thus limited.

Though the latest census figures show some 83 percent of Lithuania's population are nominally Christian in terms of cultural background (and only around six per cent of the population self-identify as "non-religious") most Lithuanians are not devoutly over even remotely religious in practice. Therefore, there is little demand from the public for any greater role of religion in the state.

In view of its overwhelmingly non-religious population, Lithuania may be regarded as a secular state with little to no role for religion in state and government. 


\section{Freedom of religion}

Freedom of religion in Lithuania is enshrined in two legal acts - the Constitution of the Republic of Lithuania (adopted in 1992) and the Law on Religious Communities and Associations (passed in 1995). In a number of its articles the Constitution guarantees religious freedom to the country's inhabitants. However, it makes an explicit distinction in Article 43 between what it refers to as "traditional" and merely "registered" "churches" and religious organizations. ${ }^{1}$ The Law on Religious Communities and Associations names nine such religious communities: Roman Catholic, Greek Catholic, Evangelical Lutheran, Evangelical Reformed, Russian Orthodox, Old Believer, Judaist, Sunni Muslim and Karaite. $^{2}$

As Article 43 of the Constitution declares that there is no state religion in Lithuania, all of the traditional religious communities named in the Law on Religious Communities and Associations are formally equal, both vis-à-vis the state and among themselves. Article 3 of the Law on Religious Communities and Associations assures that: "All individuals, regardless of religion they profess, their religious convictions or their relationship with religion, shall be equal before the law. It shall be prohibited to, directly or indirectly, restrict their rights and freedoms, or to apply privileges." 3 Nonetheless, the formal distinction between "traditional" and other religious communities allows for preferential, if not discriminatory, treatment by the state and public institutions. The inequality between religious communities has become evident in the practical application of the Law on Religious Communities and Associations in various fields, with the Roman Catholic Church being primus inter pares.

No religious organizations are banned in Lithuania, and the intelligence services do not perceive any of the religious groupings operating in the country as potentially dangerous. One can observe a hierarchization of religious collectivities in Lithuania, and the state endorses and sustains the ensuing inequalities among them through its regime of governing religious diversity. Nonetheless, practically any religious group may practice its faith unhindered insofar as it does not break the law.

\footnotetext{
${ }^{1}$ Seimas of the Republic of Lithuania, Constitution of the Republic of Lithuania, Article 43, 1992. Available at http://www3.Irs.lt/home/Konstitucija/Constitution.htm. [2019-09-27].

2 Seimas of the Republic of Lithuania, Law on Religious Communities and Associations of the Republic of Lithuania, 1995. Article 5. Traditional Religious Communities and Associations of Lithuania. Available at https://e-seimas.Irs.lt/portal/legalAct/lt/TAD/TAIS.385299?jfwid=16j6tpgu6w [2019-09-27].

${ }^{3}$ Seimas of the Republic of Lithuania, Law on Religious Communities and Associations of the Republic of Lithuania, 1995. Article 3. Equality of People Regardless of their Religion. Available at https://eseimas.lrs.lt/portal/legalAct/lt/TAD/TAIS.385299?jfwid=16j6tpgu6w [2019-09-27].
} 


\section{Religiously inspired radicalisation}

Lithuania has so far experienced few challenges stemming from violent religious radicalisation. There have been no recorded attempts to carry out acts of religiously inspired violence on its territory or against its citizens, infrastructure or interests abroad by any group or individual of any religious persuasion. In its annual reports ${ }^{4}$ the intelligence community constantly reassures society that the terrorist threat level for Lithuania and Lithuanians is very low.

No known individuals left Lithuania to join ISIS or fight for any other armed group in the Middle East or beyond. Thus, Lithuania is not faced with concerns about ISIS "foreign fighters" that many other European countries have. Nonetheless, there have been reports of individual Muslims - both Lithuanian citizens and foreigners resident in the country (or even nascent groups of them) - who may be on the path of religious radicalisation. ${ }^{5}$ Furthermore, intelligence agencies have reported 6 instances when foreign nationals residing in the country were suspected of links to religious radical groups and were subsequently deported.

Moreover, there has been one case of an alleged Lithuanian religious radical who was supposedly planning to commit a terrorist act in Russia. The person accused of planning it was a young female Lithuanian convert to Islam, whom the police apprehended in 2009 when she was about to board a flight to Russia. She was charged with planning to blow herself up somewhere in Russia (presumably in Chechnya) with the intention of damaging a Russian military facility and killing Russian soldiers. In 2013, after a prolonged trial, she was sentenced to ten months in prison. After she appealed the sentence, however, both the court of appeals and the Lithuanian Supreme Court (cassation court) acquitted her.

\footnotetext{
4 Threats for the National Security in Lithuania, State Security Department, https://www.vsd.lt/en/threats/threats-national-security-lithuania/. [2019-09-27].

5 "E. Račius: Radical Islamists thundering into Lithuania", Delfi.lt, April 19, 2017, https://en.delfi.lt/archive/e-racius-radical-islamists-thundering-into-lithuania.d?id=74403180 [201909-27].

${ }^{6}$ Threats for the National Security in Lithuania, State Security Department, https://www.vsd.lt/en/threats/threats-national-security-lithuania/. [2019-09-27].
} 


\section{Religious diversity governance assessment}

Though Lithuanian society is rather secular, people do profess numerous faiths, and the country's regime of religious diversity governance favors those religious communities that have been historically institutionalized, treating them as "traditional". The Roman Catholic Church represents the overwhelming majority of the country's believers and in practice receives more favorable treatment by the state than any other "traditional" faith community. Moreover, legislation inadvertently puts any newly emergent religious collectivities at a disadvantage. Though there have been attempts to change the legal status quo by overhauling the Law on Religious Communities and Associations, these attempts so far have been inconclusive.

There has so far been no case of religious radicalisation in Lithuania amounting to extremism or terrorism, and there are no groups of religious radicals of any persuasion. The hierarchy of the Roman Catholic Church in Lithuania has been of a peaceful and accommodating position, and no signs of radicalism have been observed. Likewise, none of the non-Christian religious communities have shown signs of religious radicalisation, though intelligence agencies have noted individual Muslims with leanings toward religious conservatism. All in all, the relevant state bodies have not had any real chances to engage in prevention or combating (violent) religious radicalisation. On the other hand, Lithuania duly follows pan-European trends in its legislation related to prevention and combating of violent religious radicalisation. Parts of its legal Code as well as the National Security Strategy take it into account.

Having no legislation that specifically targets either religious radicalisation or extremism, Lithuania has no legal definition of either "religious radicalisation" or "extremism". The most closest related legislation may be that found in the Criminal Code, where Article 170 criminalizes incitement of hatred on various grounds, including a person's religion. ${ }^{7}$ Article 170-1 of the same Code criminalizes the formation and activities of any organization that discriminates against a group of persons or incites against them. ${ }^{8}$

Lithuanian intelligence agencies in charge of prevention and combating violent religious radicalisation routinely (on an annual basis) release reports where the issue of religious radicalisation is addressed and, as a rule, is tied to Islam and Muslims. Intelligence agencies, in cooperation with relevant institutions (Migration Department, Police), facilitated neutralization of suspected foreign religious radicals by detaining and/or deporting them or denying them entry visas.

Lithuania follows EU standards in its governance of religious diversity and also seeks to update its legislation pertaining to religious radicalisation, extremism and terrorism. However, having not experienced any tensions or challenges coming from the religious sector, Lithuania has not tested its regime of governance of religious diversity. Shifts in religious demography, particularly due to migration, may potentially upset the status quo and lead to real-time challenges that will need real solutions. However, so far, the process of Lithuania's religious diversification is too slow to suggest any impending challenges.

\footnotetext{
${ }^{7}$ Criminal Code of the Republic of Lithuania https://www.unodc.org/cld/document/ltu/2000/criminal_code_of_lithuania.html [2019-09-27]. ${ }^{8}$ Criminal Code of the Republic of Lithuania https://www.unodc.org/cld/document/ltu/2000/criminal_code_of_lithuania.html [2019-09-27].
} 


\section{About the GREASE project}

Radicalisation, Secularism and the Governance of Religion: Bringing together European and Asian Perspectives (GREASE)

Involving researchers from Europe, North Africa, the Middle East, Asia and Oceania, GREASE is investigating how religious diversity is governed in over 20 countries. Our work focuses on comparing norms, laws and practices that may (or may not) prove useful in preventing religious radicalisation. Our research also sheds light on how different societies cope with the challenge of integrating religious minorities and migrants. The aim is to deepen our understanding of how religious diversity can be governed successfully, with an emphasis on countering radicalisation trends.

This document is available for download at http://grease.eui.eu/

The sole responsibility of this publication lies with the authors. The European Union is not responsible for any use that may be made of the information contained herein Any enquiries regarding this publication should be sent to:

Professor Anna Triandafyllidou, anna.triandafyllidou@eui.eu

October 2019

Document series reference: D2.2 Country Profiles

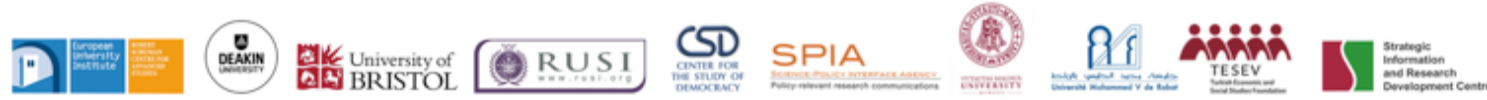

